\title{
Ephemeral hypoxia reduces oxygen consumption in the Caribbean coral Orbicella faveolata
}

\author{
Philip M. Gravinese ${ }^{1,2}$ (D) $\cdot$ Alex Douwes $^{1} \cdot$ Katherine R. Eaton $^{3} \cdot$ Erinn M. Muller $^{3}$ (I)
}

Received: 29 March 2021/Accepted: 30 October 2021/Published online: 12 November 2021

(C) The Author(s) 2021

\begin{abstract}
Oxygen concentrations in coastal waters have declined globally by $10 \%$ since the mid-twentieth century, and ocean warming will further reduce the solubility of oxygen in coastal habitats. Some nearshore reefs experience periodic hypoxic conditions due to eutrophication, especially during the wet season. Here, we determined the combined impacts of hypoxia and elevated temperature on the reef-building coral, Orbicella faveolata, by exposing corals to normoxic or hypoxic conditions and ambient or elevated temperatures. Oxygen consumption was monitored using closed-system respirometry. Corals within hypoxic conditions consumed $34 \%$ less oxygen relative to corals in normoxic conditions. Corals in the elevated temperature normoxic treatment experienced a $10 \%$ increase in oxygen consumption relative to the control. Corals exposed to both stressors simultaneously experienced a $62 \%$ reduction in oxygen consumption. These results suggest that increased temperature may exacerbate the negative effects of hypoxia on $O$. faveolata.
\end{abstract}

\section{Keywords Orbicella faveolata $\cdot$ Hypoxia $\cdot$ Ocean} warming . Coral reef

Topic editor Simon Davy

Philip M. Gravinese

pgravinese@flsouthern.edu

1 Mote Marine Laboratory, Fisheries Ecology and Enhancement Program, 1600 Ken Thompson Parkway, Sarasota, FL 34236, USA

2 Department of Biological Sciences, Florida Southern College, 111 Lake Hollingsworth Drive, Lakeland, FL 33801, USA

3 Mote Marine Laboratory, Coral Health and Disease Program, 1600 Ken Thompson Parkway, Sarasota, FL 34236, USA

\section{Introduction}

Coral reefs are some of the most biologically diverse and economically important ecosystems in the world, providing ecosystem services that are vital to coastal communities such as shoreline protection from storm surge, fisheries, and ecotourism (Moberg and Folke 1999; Storlazzi et al. 2019). For example, in the continental U.S., Florida's Coral Reef (FCR) spans 360 nautical miles along the east coast of the state from Martin County to the Dry Tortugas. Economically, the FCR has an asset value of $\$ 8.5$ billion, supports over 70,000 local jobs, and attracts 16 million visitors per year (Johns et al. 2001). Despite the biological and economic importance of coral reefs, several local and global stressors have drastically reduced live coral cover over the last several decades (Dustan 1977; Palandro et al. 2008; Ruzicka et al. 2013; Toth et al. 2019).

Global stressors such as ocean warming have contributed to a decline in live coral cover on reefs around the world (Brandt and McManus 2009; Ruzicka et al. 2013; Manzello 2015; Manzello et al. 2018; Jones et al. 2020). Additionally, stressors such as pollution, overfishing, and infectious disease outbreaks have led to further coral reef decline (Green and Bruckner 2000; Aronson and Precht 2001; Mora 2008; Jackson et al. 2017; Lapointe et al. 2019). Specifically, the Stony Coral Tissue Loss Disease (SCTLD - a multi-year disease related mortality event) has resulted in massive declines of major reef building species throughout the Caribbean over the last several years (Precht et al. 2016; Walton et al. 2018; Alvarez-Filip et al. 2019; Weil et al. 2019). Furthermore, some locations like Florida reefs, now have less than $5 \%$ live coral cover, and show little to no signs of recovery (Toth et al. 2019; Porter and Stossel 2020). In addition to the global and local stressors mentioned, some nearshore coral reefs can 
experience periods of episodic hypoxic conditions as a result of land-based runoff, especially after the wet season (Lapointe and Matzie 1996; Altieri et al. 2017; Kealoha et al. 2020). For example, Bocas del Toro, Panama, experienced a hypoxic event in 2010 where corals were subjected to oxygen levels of $<0.5 \mathrm{mg} \mathrm{L}^{-1}$ at some sites (Collin et al. 2009; Altieri et al. 2017). This location then experienced another hypoxic event in 2017 that led to a $50 \%$ loss of live coral and benthic community shifts (Johnson et al. 2021). More recently, the Flower Garden Banks in the Gulf of Mexico was reported to experience a severe hypoxic event with dissolved oxygen levels reaching $<1 \mathrm{mg} \mathrm{L}^{-1}$ in some locations (Kealoha et al. 2020). These studies further report that the negative effects of oxygen deprivation can lead to bleaching stress and eventual mortality, with some coral species being more susceptible to hypoxia than others.

The combination of elevated temperature and lower dissolved oxygen concentrations may pose additional physiological strain for some nearshore reef-building corals. Therefore, our objective was to determine the combined effect of hypoxia and elevated temperature, as singular and simultaneous stressors, on the endangered reef building coral, Oribcella faveolata, in a controlled laboratory setting. We hypothesized that exposure to: (1) elevated temperature would increase oxygen consumption, (2) hypoxia would result in sublethal effects by reducing oxygen consumption, and (3) the combined treatment (elevated temperature and hypoxia) would produce an antagonistic effect on oxygen consumption relative to the control.

\section{Materials and methods}

\section{Coral collection and fragmentation}

Two healthy $10 \mathrm{~cm} \times 10 \mathrm{~cm}$ Orbicella faveolata colonies were collected at an inshore patch reef near Big Pine Key, FL (24.60580, -81.42946) in August 2018 and maintained in the Coral Health and Disease laboratory at Mote Marine Laboratory in Sarasota, FL. These colonies were fragmented into 60 individual fragments $(n=15$ per treatment; treatments described below) using a diamond blade band saw (Gryphon Corporation, C-40 CR Aquasaw XL). Fragments were allowed to recover and grow within a flow-through raceway for approximately 10 months prior to the beginning of the experiment. During that time, corals were held in ambient water quality conditions within a narrow range (mean, \pm S.D.) of temperature $\left(27.0 \pm 0.46{ }^{\circ} \mathrm{C}\right)$, salinity $(34.2 \pm 0.87)$ and dissolved oxygen $\left(7.78 \pm 0.62 \mathrm{mg} \mathrm{L}^{-1}\right)$. Corals were maintained under a 10-h light: 14-h dark photoperiod using Radion
XR30w Pro aquaria lights (Ecotech Marine, Allentown, Pennsylvania) and were set to a "traveling sunrise and sunset" feature (50-300 mol m${ }^{-2} \mathrm{~s}^{-1}$ photosynthetically active radiation) to mimic natural conditions. Prior to exposure to the treatments, each fragment was digitally photographed and the surface area $\left(\mathrm{cm}^{2}\right)$ was quantified by digitally tracing the edge of each fragment using ImageJ software (Abràmoff et al. 2004).

\section{Experimental design}

This experiment consisted of two fully-crossed treatment parameters (i.e., temperature and dissolved oxygen), each with two levels, resulting in a total of four different treatments. We used 15 independent corals in each treatment (60 total). Caution was taken during experimentation to make sure that corals from one parent colony were not exclusively within one treatment. Corals from parent colony " $\mathrm{A}$ " had eight individuals in the control and hypoxic treatment and seven individuals in the elevated temperature and combined treatment. Corals from colony " $\mathrm{B}$ " brought the replicates to 15 in each treatment. The two temperature levels were set at $28^{\circ} \mathrm{C}$ (ambient) and $31.5^{\circ} \mathrm{C}$ (elevated). Ambient temperature conditions reflected average ambient conditions for Carysfort Reef, Florida and average summer temperatures (National Data Buoy Center 1971; Kuffner et al. 2015). The elevated temperature was set to mimic thermal conditions that corals might experience during a bleaching event. The oxygen levels consisted of a normoxic treatment $\left(>2.0 \mathrm{mg} \mathrm{L}^{-1}\right)$ and a hypoxic treatment (see Table 1 for a summary of treatment levels). We defined hypoxic as oxygen concentrations below $2 \mathrm{mg} \mathrm{O}$ $\mathrm{L}^{-1}$, while anoxic conditions were defined as the complete absence of oxygen (Diaz 2001; Breitburg et al. 2018), however, no corals experienced anoxic conditions during these experiments.

Temperature was controlled during the experiment using a thermostatically controlled flow-through water bath. The temperature of the water bath was digitally controlled using heaters and temperature probes, which were constantly monitored and maintained by AquaControllers (Apex System, Neptune). This system allowed corals to be gradually acclimated to the elevated temperature treatment by raising the temperature $0.5{ }^{\circ} \mathrm{C}$ every day over a period of seven days. Corals in the elevated temperature treatments were then maintained at $31.5^{\circ} \mathrm{C}$ for seven days prior to the start of the experiment. Corals were gradually exposed to hypoxic conditions over a two-hour period, during which the dissolved oxygen concentrations were reduced by $0.035 \mathrm{mg} \mathrm{L}^{-1}$ per minute for each temperature treatment by bubbling nitrogen gas into the seawater. Corals were dark acclimated for one hour prior to experimentation in a darkroom. After the gradual ramp down to lower dissolved 
Table 1 Temperature $\left({ }^{\circ} \mathrm{C}\right)$ and dissolved oxygen $\left(\mathrm{mg} \mathrm{L}^{-1}\right)$ with standard deviation $( \pm$ S.D.) for each experimental treatment

\begin{tabular}{lll}
\hline Treatment & Temperature $\left({ }^{\circ} \mathrm{C}\right)$ & Dissolved Oxygen $\left(\mathrm{mg} \mathrm{L}^{-1}\right)$ \\
\hline Control & $28.5( \pm 0.36)$ & $5.84( \pm 0.34)$ \\
Hypoxic & $28.6( \pm 0.15)$ & $0.77( \pm 0.53)$ \\
Elevated Temperature & $31.4( \pm 0.37)$ & $6.14( \pm 0.29)$ \\
Hypoxic + Elevated Temperature & $31.4( \pm 0.26)$ & $0.55( \pm 0.21)$ \\
\hline
\end{tabular}

oxygen concentrations, corals were maintained in hypoxic conditions (at their respective temperature treatment) for six hours in the dark, which mimicked nocturnal conditions. The corals were then placed into the respirometry chamber for one hour to measure oxygen consumption.

We acknowledge that the use of nitrogen gas to reduce oxygen concentrations will increase seawater $\mathrm{pH}$, which may be different from natural hypoxic events (Alteri et al. 2017). In our experiments, corals were exposed to hypoxia in dark conditions when only respiration is taking place, which results in a lower $\mathrm{pH}$ at the coral surface-water interface than in light conditions (Al-Horani 2005; Jokiel 2011). The magnitude of the surface $\mathrm{pH}$ decreases in the dark conditions was likely minimized due to the buffering capacity of injecting nitrogen gas used in these experiments; however, it is unlikely that this difference would have impacted oxygen consumption by the coral.

\section{Coral respirometry}

To determine the effects of the experimental treatments on coral physiology, total oxygen consumption $\left(\mu \mathrm{mol} \mathrm{L}^{-1}\right.$ ) was measured for each coral fragment. Oxygen consumption was continuously monitored over one hour using a microrespirometry chamber and oxygen probe (Unisense; $400 \mathrm{ml}$ chamber). Simultaneously, a second chamber with the same experimental conditions, but no coral was used as a "blank." This protocol allowed us to account for oxygen produced or consumed by unknown biological sources in the treatment seawater. Both chambers were sealed and submerged in a thermally controlled water bath as previously described on a submerged stir plate $(400 \mathrm{rpm})$ to ensure uniform flow. All experiments were conducted in a darkroom, and all seawater used in the respirometer was vacuum filtered $(0.1 \mu \mathrm{m})$ prior to use to minimize biological sources of respiration and photosynthesis.

Both respirometer chambers were equipped with a stir bar $(400 \mathrm{rpm})$ separated from the experimental chamber via a mesh screen, and were placed on a stir plate to ensure that the water in the chamber was well-mixed. Prior to experimentation, oxygen sensors were two-point calibrated using anoxic seawater bubbled with nitrogen gas $(0 \%$ oxygen concentration) and saturated seawater bubbled with air (100\% oxygen). Both oxygen electrodes relayed realtime measurements within the respirometers every second for $65 \mathrm{~min}$ to a computer for data output using data acquisition software (Unisense, AutoResp). We counted the first $5 \mathrm{~min}$ of every trial as an additional acclimation period, which were not included in the analyses. We used the total amount of oxygen consumed $\left(\mu \mathrm{mol} \mathrm{L}^{-1}\right)$ after $60 \mathrm{~min}$ as the primary metric for evaluating the impact of our treatments on coral respiration.

\section{Data analysis}

The total amount of oxygen consumed $\left(\mu \mathrm{mol} \mathrm{L}^{-1}\right)$ after $60 \mathrm{~min}$ did not meet the assumptions of normality and were, therefore, rank transformed (Conover and Iman, 1981). A linear mixed effects model was run on the ranked data, with temperature and dissolved oxygen as fixed factors and coral as a random factor. All statistical analyses were performed using R (R Core Team, 2021).

\section{Results and discussion}

Coral reefs around the world are increasingly impacted by thermal extremes, which have been responsible for widespread coral bleaching and mortality (Hughes et al. 2017). For example, both warm and cold extremes have caused declines in reef-building coral populations in south Florida (Lirman et al. 2011; Manzello 2015; Manzello et al. 2015; Jones et al. 2020); however, less is known about the sublethal impacts of both thermal extremes and reduced dissolved oxygen on coral physiology. On average, $O$. faveolata in the control consumed $6.37 \mu \mathrm{mol} \mathrm{L}^{-1}$ of oxygen after $60 \mathrm{~min}$ in dark conditions, while corals exposed to elevated temperature consumed $7.05 \mu \mathrm{mol} \mathrm{L}{ }^{-1}$. The difference in oxygen consumption under normoxic conditions was not statistically different from the control (elevated temperature: $\mathrm{F}_{1,56}=0.02, P=0.86$; Fig. 1, Table 2). Al-Horani (2005) found that Indo-pacific corals also consumed more oxygen at elevated temperature $\left(32{ }^{\circ} \mathrm{C}\right)$; however, the increase in that experiment was observed under light conditions and was associated with a decrease in photosynthesis which was not the case in our experiment that was conducted in dark conditions. Elevated seawater temperatures are known to increase respiration rates and have been reported in other species like Montipora sp. (Coles and Jokiel 1977; Porter et al. 1999). The lack of a 
Fig. 1 The amount of oxygen $\left(\mu \mathrm{mol} \mathrm{L}{ }^{-1} ; \pm \mathrm{SE}\right)$ consumed during $1 \mathrm{~h}$ respirometry trials for Orbicella favolata $(n=15$ per treatment) exposed to hypoxia and elevated temperature as singular and simultaneous stressors. Letters denote significant differences at $\alpha=0.05$ using a mixed effects model with temperature and dissolved oxygen as fixed factors

\section{Treatments}

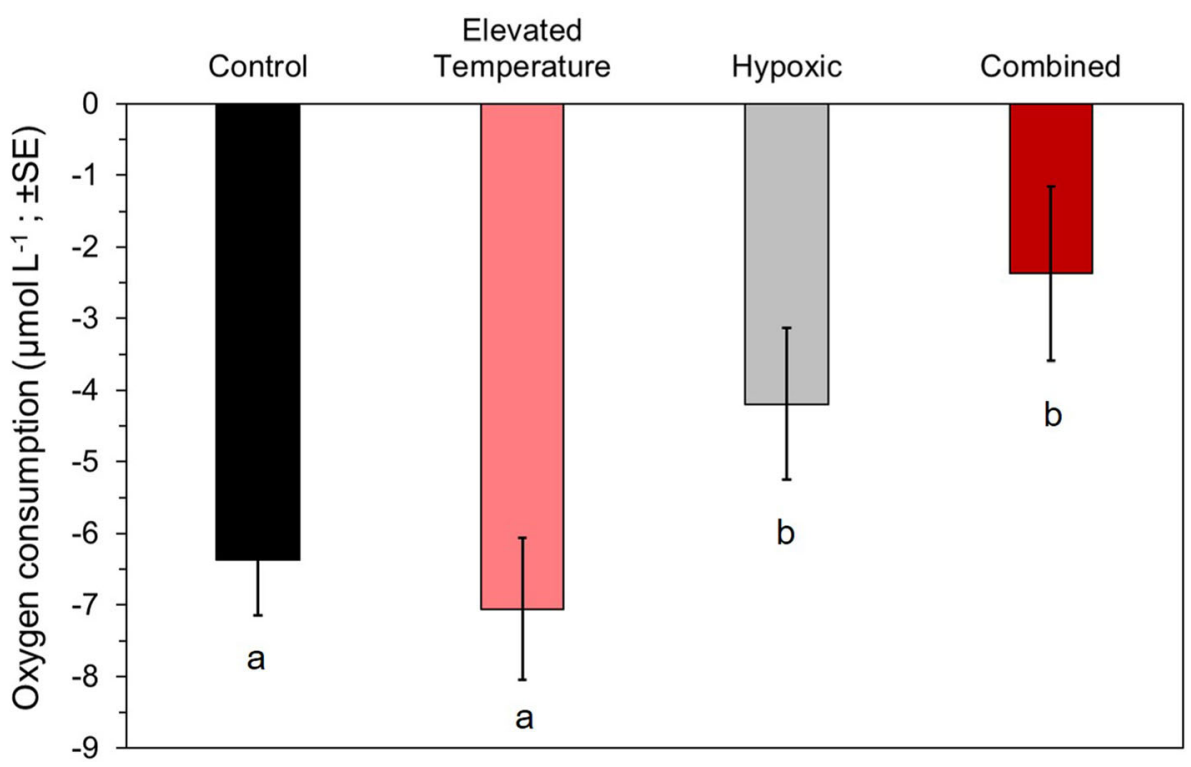

Table 2 The statistical results from the linear mixed effect model with the main effects and the interaction between the two treatments

\begin{tabular}{llll}
\hline Main effects and interaction & F & d.f & $P$ \\
\hline Temperature & 0.02 & 1,56 & 0.86 \\
Dissolved oxygen & 7.5 & 1,56 & $\mathbf{0 . 0 0 7}$ \\
Temperature*Dissolved oxygen & 0.36 & 1,56 & 0.55 \\
Post-hoc test & $\mathrm{t}$ & & $\mathrm{P}$ \\
Normoxic: Ambient vs. elevated temperature & -1.52 & & 0.43 \\
Hypoxic: Ambient vs. elevated temperature & -2.37 & & 0.09 \\
\hline
\end{tabular}

The post-hoc Tukey results for dissolved oxygen are also presented Statistically significant $P$ values are in bold

significant effect at elevated temperature in these experiments is most likely due to biological variation among the corals and our lower level of replication.

Corals in both nearshore and offshore environments, throughout parts of the Caribbean and within the Flower Garden Banks, may be periodically subjected to excess nutrients associated with runoff during the wet season, especially after major storm events (Lapointe et al. 2004; Altieri et al. 2017; Kealoha et al. 2020). These excess nutrients can cause episodic hypoxic events in some habitats (Lipp et al. 2002; Altieri et al. 2017; Kealoha et al. 2020). Here, we show that corals exposed to hypoxic conditions as a singular stressor experienced a significant decrease in the amount of oxygen consumed (dissolved oxygen: $\mathrm{F}_{1,56}=7.5, P=0.007$; Fig. 1 , Table 2 ). Corals in the hypoxic treatment consumed $4.19 \mu \mathrm{mol} \mathrm{L}^{-1}$ of oxygen, which was representative of a $34.2 \%$ decrease in oxygen consumed relative to corals in the control. Corals in the combined elevated temperature and hypoxic treatment consumed almost two times less oxygen $\left(2.37 \mu \mathrm{mol} \mathrm{L}^{-1}\right.$ of oxygen), which was representative of a $62.8 \%$ decrease relative to the control. We did not observe a significant interaction effect between temperature and the dissolved oxygen treatments $\left(\mathrm{F}_{1,56}=0.36, P=0.55\right.$, Table 2$)$.

In the present study, corals were still utilizing aerobic respiration pathways in all treatments, as we observed reductions in oxygen concentrations after $60 \mathrm{~min}$ of measurement, albeit less effectively in some treatments. This suggests that $O$. faveolata may have some tolerance to short-term hypoxic exposure (i.e., diurnal changes). The observed reduction in oxygen consumption during hypoxic stress may, therefore, be associated with a gradual shift to anaerobic respiration in $O$. faveolata. Experiments with longer-term exposure are therefore needed to assess whether hypoxia could cause a complete shift to anaerobic respiration and to identify what those impacts may be on coral physiology. Some cnidarians have been reported to be able to survive hypoxic and even anoxic conditions for greater than three and five days of exposure, respectively (Martinez et al. 2012; Murphy and Richmond 2016); however, tolerance to reduced oxygen in the short-term comes at a metabolic cost (Martinez et al. 2012; Murphy and Richmond 2016). Cnidarians can tolerate acute hypoxic periods by shifting their metabolism to use less efficient forms of respiration (e.g., anaerobic respiration pathways) and converting pyruvate to lactate or some other enzyme during glycolysis (Murphy and Richmond 2016). These metabolic shifts during hypoxic exposure can often lead to bleaching of the colony (Zhu et al. 2004; Altieri et al. 2017; Nelson and Altieri 2019). Although we did not 
directly measure or quantify bleaching, we did observe some paling in our hypoxic corals at the completion of these experiments.

Massive corals are usually more tolerant to hypoxic conditions relative to branching coral species (Guzmán et al. 1990; Simpson et al. 1993; Andréfouët et al. 2001). Similarly, our results suggest that $O$. favelota is able to tolerate short-term exposure to hypoxia as we did not observe any mortality during our experiments and corals were still consuming oxygen albeit at a lower rate. The coral fragments used in this study were monitored for two months after the study concluded. None of the coral fragments died during that two month period suggesting that the response observed was indeed sub-lethal. The oxygen thresholds for exposure are unknown for most reef-building corals and only a few studies have reported the effects of both elevated temperature and hypoxia on coral physiology or survival (Hughes et al. 2020). This is likely because low oxygen events in the tropics are not as well categorized as hypoxic events documented in more temperate zones (Kealoha et al. 2020), even though tropical reef communities are particularly vulnerable to deoxygenation events (Hughes et al. 2020). Exposure to both hypoxia and elevated temperature simultaneously showed a negative response with an almost two times the reduction in oxygen demand in $O$. faveolota suggesting a trend toward a synergistic effect whereby increased temperature exacerbates the negative effect of hypoxia (post hoc result: $P=0.09$, Table 2). Although some studies have described that $O$. faveolata appear highly resistant to ocean warming (Manzello et al. 2015, 2018), exposure to hypoxic stress may accelerate bleaching and mortality. Temperatures are expected to increase five times faster in the twenty-first century compared with the $0.6{ }^{\circ} \mathrm{C}$ warming rate documented for the twentieth century (Kerr et al. 2004) and some habitats (i.e., the Florida Keys) have already experienced a $0.8{ }^{\circ} \mathrm{C}$ increase in sea surface temperature over the last century (Kuffner et al. 2015). Thermal stress, therefore, will undoubtedly decrease oxygen solubility in coastal habitats into the future, leading to more hypoxia, which may exacerbate some coral's ability to acclimate and survive additional increases in temperature. Future work should determine the long-term tolerance of $O$. faveolota to hypoxic stress and identify the coral's susceptibility to bleaching and disease when exposed to both stressors.

Acknowledgements We thank the Steinwachs Family Foundation, which provided funding that supported Gravinese's postdoctoral fellowship at Mote Marine Laboratory and Aquarium. Douwes was supported by a Mote Research Experience for Undergraduates. Funding for EMM was provided in part by a Mote Eminent Scholarship and also the Garden Club of Sarasota for both EMM and KRE. Coral collections were completed under permit \# FKNMS-2017-135A1. We thank F. Lach and R. Banister for assistance with this project.

\section{Declarations}

Conflict of interest On behalf of all authors, the corresponding author states that there is no conflict of interest.

Open Access This article is licensed under a Creative Commons Attribution 4.0 International License, which permits use, sharing, adaptation, distribution and reproduction in any medium or format, as long as you give appropriate credit to the original author(s) and the source, provide a link to the Creative Commons licence, and indicate if changes were made. The images or other third party material in this article are included in the article's Creative Commons licence, unless indicated otherwise in a credit line to the material. If material is not included in the article's Creative Commons licence and your intended use is not permitted by statutory regulation or exceeds the permitted use, you will need to obtain permission directly from the copyright holder. To view a copy of this licence, visit http://creativecommons. org/licenses/by/4.0/.

\section{References}

Abràmoff MD, Magalhães PJ, Ram SJ (2004) Image processing with image. J Biophoton Int 11(7):36-41

Al-Horani FA (2005) Effects of changing seawater temperature on photosynthesis and calcification in the scleractinian coral Galaxea fascicularis, measured with $\mathrm{O} 2, \mathrm{Ca} 2+$ and $\mathrm{pH}$ microsensors. Scimar 69(3):347-354

Altieri AH, Harrison SB, Seemann J, Collin R, Diaz RJ, Knowlton N (2017) Tropical dead zones and mass mortalities on coral reefs. Proc Natl Acad Sci USA 114(14):3660-3665

Alvarez-Filip L, Estrada-Saldívar N, Pérez-Cervantes E, MolinaHernández A, González-Barrios FJ (2019) A rapid spread of the stony coral tissue loss disease outbreak in the Mexican Caribbean. Peer J. https://doi.org/10.7717/peerj.8069

Andréfouët S, Payri C, Adjeroud M (2001) Mass mortality of macrobenthic communities in the lagoon of Hikueru atoll (French Polynesia). Coral Reefs 19(3):287-291

Aronson RB, Precht WF (2001) White-band disease and the changing face of Caribbean coral reefs. The ecology and etiology of newly emerging marine diseases. Dev Hydrobiol. https://doi.org/10. 1007/978-94-017-3284-0_2

Brandt ME (2009) The effect of species and colony size on the bleaching response of reef-building corals in the Florida Keys during the 2005 mass bleaching event. Coral Reefs 28:911-924

Breitburg D, Levin LA, Oschlies A, Chavez GM et al (2018) Declining oxygen in the global ocean and coastal waters. Science. https://doi.org/10.1126/science.aam7240

Coles SL, Jokiel PL (1977) Effects of temperature on photosynthesis and respiration in hermatypic corals. Mar Biol 43:209-216

Collin R, D’Croz L, Gondola P, Del Rosario JB (2009) Climate and hydrological factors affecting variation in chlorophyll concentration and water clarity in the Bahia Almirante, Panama. Smithson Contrib Mar Sci 38:323-334

Conover WJ, Iman RL (1981) Rank transformations as a bridge between parametric and nonparametric statistics. Am Stat 35(3): $124-129$

Diaz RJ (2001) Environmental quality overview of hypoxia around the world. J Environ Qual 30(2):275-281

Dustan P (1977) Vitality of reef coral populations off Key Largo, Florida: Recruitment and mortality. Environ Geol 2(1):51-58

Green EP, Bruckner AW (2000) The significance of coral disease epizootiology for coral reef conservation. Biol Cons 96(3):347-361. https://doi.org/10.1016/S0006-3207(00)00073-2 
Guzmán H, Cortés J, Glynn P, Richmond R (1990) Coral mortality associated with dinoflagellate blooms in the eastern Pacific (Costa Rica and Panama). Mar Ecol Prog Ser 60(3):299-303

Hughes TP, Barnes ML, Bellwood DR, Cinner JE, Cumming GS, Jackson JB, Kleypas J, Van De Leemput IA, Lough JM, Morrison TH, Palumbi SR (2017) Coral reefs in the Anthropocene. Nature 546(7656):82-90

Hughes DJ, Alderdice R, Cooney C (2020) Coral reef survival under accelerating ocean deoxygenation. Nat Clim Chang 10:296-307

Jackson JBC, Kirby MX, Berger WH, Karen A, Botsford LW, Bourque BJ, Bradbury RH, Cooke R, Estes JA, Hughes TP, Kidwell S, Lange CB, Hunter S, Pandolfi JM, Peterson CH, Steneck RS, Tegner MJ, Warner RR, Jackson JBC, Warner RR (2017) Historical overfishing and the recent collapse of coastal ecosystems. Science 293(5530):629-638

Johns GM, Leeworthy VR, Bell FW, \& Bonn MA (2001) Socioeconomic of Reefs in Southeast Florida. Environ Protect, 1-348

Johnson MD, Scott JJ, Leray M, Lucey N, Bravo LMR, Wied WL, Altieri AH (2021) Deoxygenation on a Caribbean coral reef. Nat Commun. https://doi.org/10.1038/s41467-021-24777-3

Jokiel PL (2011) Ocean acidification and control of reef coral calcification by boundary layer limitation of proton flux. Bull Mar Sci 87(3):639-657

Jones NP, Figueiredo J, Gilliam D (2020) Thermal stress-related spatiotemporal variations in high-latitude coral reef communities. Coral Reefs 39:1661-1673

Kealoha AK, Doyle SM, Shamberger KEF, Sylvan JB, Hetland RD, DiMarco SF (2020) Localized hypoxia may have caused coral reef mortality at the Flower Garden Banks. Coral Reefs 39(1):119-132

Kerr Y, Lagourarde JP, Nerry F, \& Ottle C (2004). Land surface temperature retrieval techniques and applications. Thermal remote sensing in land surface processes CRC Press 0-415-30224-2

Kuffner IB, Lidz BH, Hudson JH (2015) A century of ocean warming on florida keys coral reefs: historic in situ observations. Estuaries Coasts 38:1085-1096

Lapointe BE, Matzie WR (1996) Effects of stormwater nutrient discharges on eutrophication processes in nearshore waters of the Florida Keys. Estuaries 19(2):422-435

Lapointe BE, Barile PJ, Matzie WR (2004) Anthropogenic nutrient enrichment of seagrass and coral reef communities in the Lower Florida Keys: discrimination of local versus regional nitrogen sources. J Exp Mar Biol Ecol 308(1):23-58

Lapointe BE, Brewton RA, Herren LW, Porter JW, Hu C (2019) Nitrogen enrichment, altered stoichiometry, and coral reef decline at Looe Key, Florida Keys, USA: a 3-decade study. Mar Biol. https://doi.org/10.1007/s00227-019-3538-9]

Lipp EK, Huq A, Colwell RR (2002) Effects of global climate on infectious disease: the cholera model. Clin Microbiol Rev 15(4):757-770

Lirman D, Schopmeyer S, Manzello D, Gramer LJ, Precht WF, Muller-Karger F, Banks K, Barnes B, Bartels E, Bourque A, Byrne J (2011) Severe 2010 cold-water event caused unprecedented mortality to corals of the Florida reef tract and reversed previous survivorship patterns. PLoS ONE 6(8):e23047

Manzello DP (2015) Rapid recent warming of coral reefs in the florida keys. Sci Rep 5:1-10

Manzello DP, Enochs IC, Kolodziej G, Carlton R (2015) Recent decade of growth and calcification of Orbicella faveolata in the Florida Keys: an inshore-offshore comparison. Mar Ecol Prog Ser 521:81-89

Manzello DP, Enochs IC, Kolodziej G, Carlton R, Valentino L (2018) Resilience in carbonate production despite three coral bleaching events in 5 years on an inshore patch reef in the Florida Keys. Mar Biol 165(6):1-11

Martinez JA, Smith CM, Richmond RH (2012) Invasive algal mats degrade coral reef physical habitat quality. Estuar Coast Shelf Sci 99:42-49
Moberg F, Folke C (1999) Ecological goods and services of coral reef ecosystems. Ecol Econ 29(2):215-233

Mora C (2008) A clear human footprint in the coral reefs of the Caribbean. Proc Royal Soc B Biol Sci 275(1636):767-773. https://doi.org/10.1098/rspb.2007.1472

Murphy JWA, Richmond RH (2016) Changes to coral health and metabolic activity under oxygen deprivation. Peer J. https://doi. org/10.7717/peerj.1956]

Nelson HR, Altieri AH (2019) Oxygen: the universal currency on coral reefs. Coral Reefs 38:177-198

Palandro DA, Andréfouët S, Hu C, Hallock P, Müller-Karger FE, Dustan P, Callahan MK, Kranenburg C, Beaver CR (2008) Quantification of two decades of shallow-water coral reef habitat decline in the Florida Keys National Marine Sanctuary using Landsat data (1984-2002). Remote Sens Environ 112(8):3388-3399

Porter J, Stossel M (2020) Coral reef evaluation and monitoring project florida keys 2001. United States Geol Surv. https://doi. org/10.15468/ky6rst

Porter JW, Lewis SK, Porter KG (1999) The effect of multiple stressors on the Florida Keys coral reef ecosystem: a landscape hypothesis and a physiological test. Limnol Oceanogr 44(3part2):941-949

Precht WF, Gintert BE, Robbart ML, Fura R, Van Woesik R (2016) Unprecedented disease-related coral mortality in Southeastern Florida. Sci Rep 6:1-11

R Core Team (2021). R: a language and environment for statistical computing. R Foundation for Statistical Computing. Vienna, Austria. URL https://www.R-project.org/

Ruzicka RR, Colella MA, Porter JW, Morrison JM et al (2013) Temporal changes in benthic assemblages on Florida Keys reefs 11 years after the 1997/1998 El Niño. Mar Ecol Prog Ser 489:125-141

Simpson CJ, Cary JL, Masini RJ (1993) Destruction of corals and other reef animals by coral spawn slicks on Ningaloo Reef, Western Australia. Coral Reefs 12(3-4):185-191

Storlazzi CD, Reguero BG, Cole AD, Lowe E, Shope JB, Gibbs AE, Nickel BA, McCall RT, Van Dongeren AR, \& Beck MW (2019) Rigorously valuing the role of U.S. coral reefs in coastal hazard risk reduction. U.S. Geological Survey Open-File Report 2019-1027. https://doi.org/10.3133/ofr20191027

Toth LT, Stathakopoulos A, Kuffner IB, Ruzicka RR, Colella MA, Shinn EA (2019) The unprecedented loss of Florida's reefbuilding corals and the emergence of a novel coral-reef assemblage. Ecology 100(9):e02781

US DOC/NOAA/NWS/NDBC > National Data Buoy Center (1971) Meteorological and oceanographic data collected from the National Data Buoy Center Coastal-Marine Automated Network (C-MAN) and moored (weather) buoys. MLRF1. NOAA National Centers for Environmental Information. Dataset. https://accession.nodc.noaa.gov/NDBCCMANWx

Walton CJ, Hayes NK, Gilliam DS (2018) Impacts of a regional, multi-year, multi-species coral disease outbreak in Southeast Florida. Front Mar Sci 5:1-14

Weil E, Hernández-delgado EA, Gonzalez M, Williams S, Figuerola M (2019) Spread of the new coral disease "SCTLD " into the Caribbean: implications for Puerto Rico. 34(1), 38-43

Zhu B, Wang G, Huang B, Tseng CK (2004) Effects of temperature, hypoxia, ammonia and nitrate on the bleaching among three coral species. Chin Sci Bull 49(18):1923-1928. https://doi.org/ $10.1007 / \mathrm{bf} 03184283$

Publisher's Note Springer Nature remains neutral with regard to jurisdictional claims in published maps and institutional affiliations. 